\title{
How will climate change alter the dynamics of airborne pollen and pollen load of allergenic plants?
}

\section{The "exceptionally warm year" 2018 in Linz (Upper Austria) - a potential model for the future based on long-term trends}

\author{
Herwig A. E. Schinko · Bernd Lamprecht · Roland Schmidt
}

Received: 12 December 2019 / Accepted: 5 August 2020 / Published online: 8 December 2020

(C) The Author(s) 2020

\begin{abstract}
Summary
Background Globally, climate change is being observed. Pollen allergies have been increasing since the middle of the last century. Outdoors, sensitization against pollen allergens is responsible for the highest prevalence of allergies of eyes and airways. Hence, the following two questions arose: (1) How does climate change become manifest locally-regionally, and do temperatures and precipitation have to be considered exceptional in 2018? (2) How do changing meteorological conditions impact on pollination and pollen load?

Methods Pollen data of the main allergenic plants-collected at the pollen monitoring station Linz, Upper Austria-were analysed; 2018 was compared to the years 1993-2017. By means of statistical methods, the impact of meteorological parameters on pollen seasons and pollen load were examined.

Results Climate change was confirmed for the region. The regional climate has shifted from moderate to warmer and drier (semi-arid) conditions. Preseasonal cumulated meteorological parameters determined flowering and pollen seasons (PS). Start and duration of the pollination of hazel, alder, birch, and grass followed other rules than the seasonal pollen
\end{abstract}

H. A. E. Schinko, MD (ه)

Department of Pneumology, former AKh Linz,

General Hospital of the City of Linz, present

Medical Campus III, Kepler University Clinics,

Bergweg 16, A-4203 Altenberg/Linz, Austria

herwig@schinko.co.at

B. Lamprecht

Pneumology, Medical Campus III, Kepler University Clinics, Linz, Austria

R. Schmidt

Pollenwarndienst (Pollen information service) Upper

Austria, Mondsee, Austria production, termed seasonal pollen integral (SPIn). By its hybrid character, the model-year 2018 offered the unique chance to generate and explain different scenarios of pollen emission and transmission. For the start of flowering of hazel (Corylus), alder (Alnus) and birch (Betula), the coincidence of cumulated mean daily warmth ( $\left.\mathrm{MDW}_{\text {cumul }}\right)$ and a distinct threshold for the highest temperature of a day (HTD) is necessary and species-specific. In 2018, the earliest begin of the pollen season (PSB) was observed. Frost delayed the PSB. Preseasonal frost as well as cool temperatures caused SPIn of alder and birch to rise, whereas SPIn of hazel were increased by warmer temperatures. Warm weather prolonged pollen seasons of early flowering plants. Heat combined with drought shortened PS of birch in 2018. Cumulated relative humidity ( $\mathrm{RH}_{\text {cumul }}$ ) correlated highly significant with the PSB of grasses. Warm and dry conditions in 2018 caused the earliest PSB of grass since 1993. Over the years, SPI and major pollen peaks of grasses have decreased, primarily due to dryness.

Conclusion The assumption that climate warming in Linz over 26 years should have increased pollen concentrations of allergenic plants was not confirmed. On the contrary, trend analyses showed that the pollen load has decreased. Hence, the increase in sensitization to pollen allergens and of the prevalence of pollen allergies ask for other explanations.

Keywords Climate change · Allergenic plants . Pollination/pollen season · Meteorological scenarios · Linz (Upper Austria)

Abbreviations

HTD Highest temperature of a day

LTD Lowest temperature of a day 
MDF Mean daily frost $={ }_{1} \int^{24}$ hourly temperatures $<0^{\circ} \mathrm{C} / 24 \mathrm{~h}$; frost is defined as temperature $<0^{\circ} \mathrm{C}$, with the freezing temperature of water being considered the physiological threshold for plant vegetation

$\mathrm{MDF}_{\text {cumul }}$ Mean daily frost cumulated starting from January 1 for each year

MDW Mean daily warmth $={ }_{1} \int{ }^{24}$ hourly temperatures $>0{ }^{\circ} \mathrm{C} / 24 \mathrm{~h}$

$\mathrm{MDW}_{\text {cumul }}$ Mean daily warmth/temperatures $>0{ }^{\circ} \mathrm{C}$ cumulated starting from January 1 for each year

MTD Mean temperature of a day $={ }_{1} \int{ }^{24}$ hourly temperatures $/ 24 \mathrm{~h}$

PC Mean pollen concentration of a day noted as pollen $/ \mathrm{m}^{3}$ air

PREC Daily precipitation in $\mathrm{mm}=\mathrm{L} / \mathrm{m}^{2}$

PREC $_{\text {cumul }}$ Daily precipitation cumulated starting from January 1

PS Pollen season-pollination

PSB Begin of pollen season-onset of pollination/flowering: phenologically defined as the first day for hazel, alder and birch, reaching 10 pollen $/ \mathrm{m}^{3}$ (PC10) or 5 pollen $/ \mathrm{m}^{3}$ (PC5) with grass species

PSE End of flowering/pollination-last day with pollen concentration identical to PSB

RH Relative humidity in \%=effective pressure of water vapour in air/maximal pressure at the saturation point, determined by temperature

$\mathrm{RH}_{\text {cumul }} \quad \mathrm{RH}$ cumulated starting from January 1

SPIn Seasonal Pollen Integral=sum of mean daily pollen counts (PC) of a season

\section{Background}

Pollen are among the most important allergen carriers outdoors. In Austria at least in children, sensitization and aero-allergies depend on the pollen load [1]. In polluted urban areas allergen-specific IgEs were found to be higher (37.8\%) as compared to rural areas (25.6\%) [2]. Recently in Salzburg, $53.5 \%$ out of 501 unselected teens at an age between 12 and 21 were found to be sensitized against pollen allergens, $26 \%$ against Phl p 1 (grass allergen group 1) and $16.3 \%$ against Bet $\mathrm{v} 1$ (main allergen of birch). The prevalence of sensitization was as high as $41.7 \%$ and dominated by birch and grass [3].

Because of global warming, accelerated at least since 1980, and an increase in $\mathrm{CO}_{2}$ in the air from about 300 to $400 \mathrm{ppm}$ (parts per million) over the past century, an increased pollen load is expected by some scientists [4]. However, comparisons of pollen counts of allergenic plants between different pollen monitoring stations around Europe did not reveal an accordant increase [5]. Diverging pollen trends between allergenic early flowering trees/shrubs and herbal summer plants contributed to a heterogenic pattern of the impact of climate change [6]. The warm and dry "model year 2018" was compared to the regional weather conditions over the past 25 years. Studying their meteorological impact on pollen counts of alder, hazel, birch and grasses should have enabled us to evaluate recent hypotheses on pollination.

According to the Zentralanstalt für Meteorologie und Geodynamik (ZAMG, Central Institute for Meteorology and Geodynamics) in Vienna, 2018 was the warmest among the past 251 years of meteorological recording (since 1768, 14 of the 20 warmest years have occurred during the 2000s). It is characterized by $12.2^{\circ} \mathrm{C}$, the highest yearly mean of temperature, $2.3^{\circ} \mathrm{C}$ above 1980 and the driest year since 1852 , reflected by a $42 \%$ drop of precipitation [7]. From 1993 to 2017 , the yearly mean of the highest temperatures of a day $\left(\mathrm{HTD}_{\mathrm{ym}}\right)$, of the lowest daily temperatures $\left(\mathrm{LTD}_{\mathrm{ym}}\right)$ as well as of the mean temperatures $\left(\mathrm{MTD}_{\mathrm{ym}}\right)$ have risen progressively. In 2018, all three values were above the expected trend. Precipitation has not dropped significantly over 25 years, but was extremely low in 2018 (Fig. 1a). With an increasing frequency of heat waves the danger of droughts has risen, too, especially in a region predisposed to low rainfall [8]. The climate change in Linz is reflected by increasing numbers of days $>20^{\circ} \mathrm{C}\left(\mathrm{R}^{2}=0.26 ; p=0.009\right)$ and $>25^{\circ} \mathrm{C}\left(\mathrm{R}^{2}=0.18 ; p=0.035\right)$ in the years 1993 to 2017 . Simultaneously, frost decreased significantly until $2018\left(\mathrm{R}^{2}=0.16 ; p=0.027\right)$. January 2018 was rather warm $\left(4.5^{\circ} \mathrm{C}\right.$ above the monthly average $)$ and, at the same time, with a precipitation of $97 \mathrm{~mm}$, the wettest within the past 26 years. After cold spells in February and March 2018, the air has become warmer, reaching temperatures in April counting to the warmest of the last quarter of the century. This period was accompanied by ongoing dryness (relative humidity RH in April: only 51.8\%-see also Fig. 8). In 2018, over 10 months temperatures were above the average of 1993-2017. However in two months they had fallen significantly below the monthly mean (Fig. 1b), characterizing 2018 as a hybrid year.

The most obvious consequence of climate warming is an "early spring" [9, 10]. According to Keenan et al. [11], this forward shift results in an earlier termination of vegetation. In the Northern biosphere, the enhanced $\mathrm{CO}_{2}$ emission could have increased the biomass of plants [12], but this effect might be outweighed by repeated phases of low or even lacking precipitation during summer and fall [13]. In clinicopalynological terms, onset, duration and intensity of pollination define the pollen season [14]. For the forecast of its beginning, the Austrian Pollenwarndienst (pollen information service) used the highest temperatures of a day (HTD) [15-17] and cumulated mean daily temperatures (MTD cumul [18] summed up from December 1, of the previous year, or January 1, of the present year. The reasoning was that (a) in Cen- 
$\mathrm{HTD}_{93-18}=0.0722 \mathrm{x}-129.9$

$R^{2}=0.3455 p=0.0016$
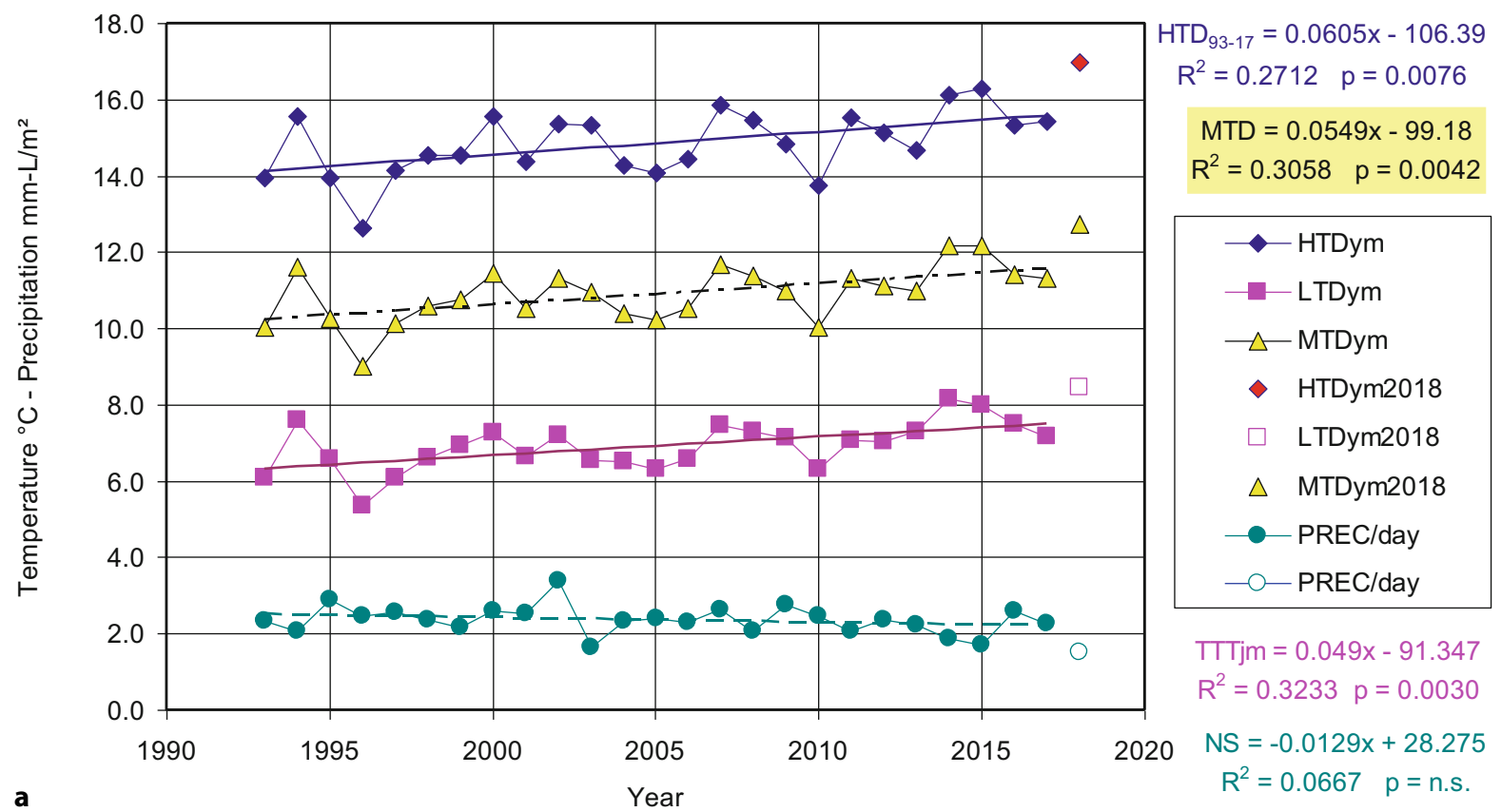

TाTjm $=0.049 x-91.347$

$R^{2}=0.3233 p=0.0030$

NS $=-0.0129 x+28.275$

$R^{2}=0.0667 p=$ n.s.

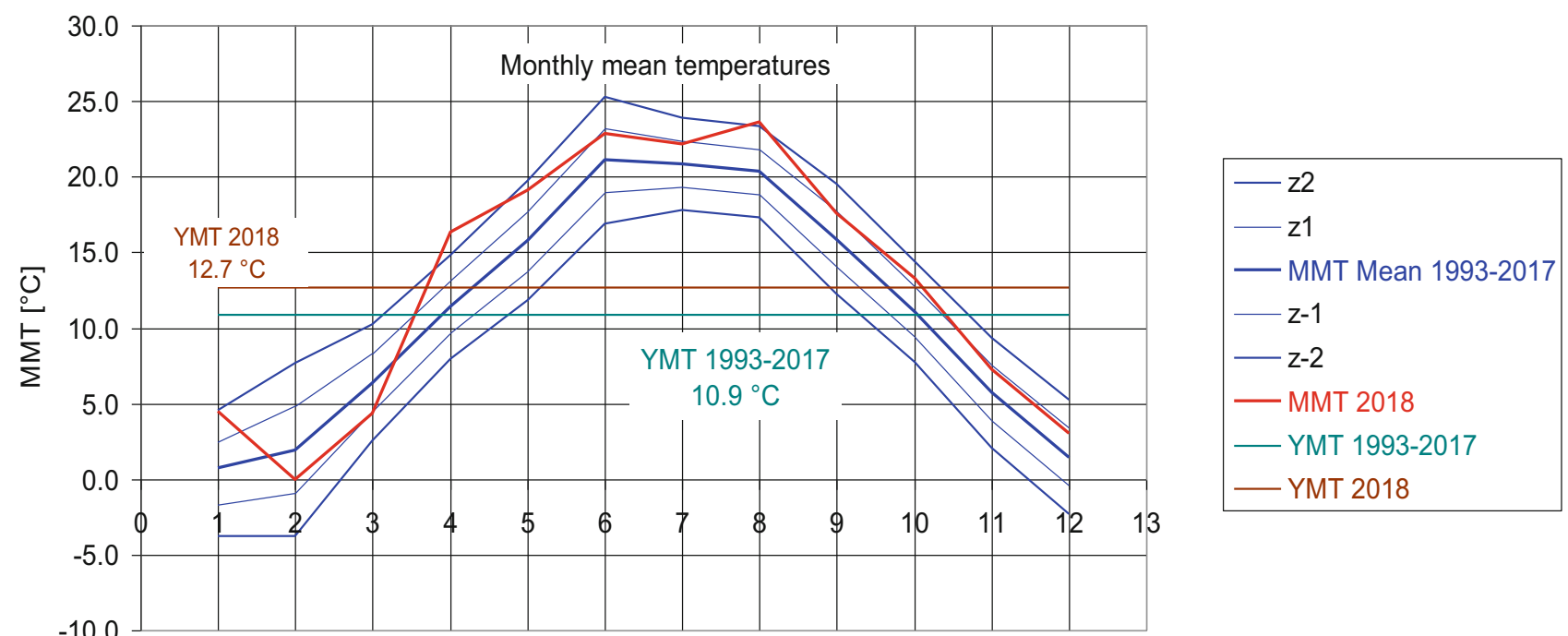

b

Months Jan-Dec (1-12)

Fig. 1 a Means of highest, mean and lowest temperatures of a year as well as daily means of precipitation in Linz-2018 vs. 1993 through 2017. While there was no significant reduction with precipitation, temperatures increased significantly between 1.53 and $1.81^{\circ} \mathrm{C}$. b Yearly and monthly mean temperatures in Linz-2018 vs 1993 through 2017. In 2018 MMTs were above average in 10 of 12 months ("warm year"). February and March were characterized by MMTs below average caused by

tral Europe trees and shrubs need a cold stimulus for further temperature-dependent development of their catkins $[19,20]$ and (b) from the phenological point of view, cumulated temperature is the primary driving force for hazel, alder and birch [21]. With hazel bud- frost. Accordingly, 2018 was a heat-frost year, being therefore a hybrid one. That had different impacts on early (hazel, alder, birch) and summer bloomers (grass species). $H T D_{y m}$ yearly means of the highest temperatures a day, $M T D_{y m}$ yearly mean of daily mean temperatures, $L T D_{y m}$ yearly mean of the lowest temperatures a day, $y m$ yearly mean, $P R E C$ daily precipitation, YMT yearly mean temperature, $M M T$ monthly mean temperature

ding and growth of leaves follow the bloom, whereas with birch both processes occur together. Allergenic summer plants (grass and herbs) differ in this regard. Growth and differentiation occur in the same year before flowering. For them favourable "start-up-con- 
ditions"-like temperature, precipitation and relative humidity-are important [22].

\section{Study area}

Linz, the capital of Upper Austria, situated 260 meter ( $\mathrm{m}$ ) above the Adriatic Sea, is an industrial city with about 200,000 inhabitants and 300,000 more in the surrounding area. The town covers 96 square kilometers $\left(\mathrm{km}^{2}\right)$, is located at the bend of the Danube at the transition from the hills of the Bohemian Cristalline Massif (at altitudes up to $930 \mathrm{~m}$ ) to a basin which is open towards the prealpine plain (S-SW). Its area comprises

- $34.8 \%$ built-up areas, including industry

- $11.6 \%$ traffic areas

- $6.4 \%$ waters

- $47.3 \%$ forest and grassland

Main pollen catchment areas for alder (Alnus glutinosa and A. incana) are the riverside/riparian forests of the Danube and her tributaries, and the green belt around the town for birch (Betula pendula), hazel (Corylus avellana) and grass (Poaceae).

\section{Methods}

The pollen monitoring station in Linz (ATLINZ, $\mathrm{N} 48.303179 / \mathrm{E} 14.305636^{\circ}$, start 1985) of the Upper Austrian Pollenwarndienst [23] uses a Burkard pollen trap. It is installed $20 \mathrm{~m}$ above ground on the roof of the Kepler University Clinic, Medical Campus III (formerly AKh-General Hospital Linz). Pollen counts have been carried out by the same analyst since 1987 in a standardized manner [24], using a light microscope. The mean pollen concentrations per $\mathrm{m}^{3}$ air $\left(\mathrm{PC}=\right.$ pollen $/ \mathrm{m}^{3}$ ) are transferred to the EAN (European Aeroallergen Network) data bank, run in cooperation with the Austrian Pollenwarndienst in Vienna. Data for this study were retrieved from there. Seasonal sums of mean daily PCs are called seasonal pollen integral (SPIn) [25]. Data of serial pollen counts for alder, hazel, birch and grass, having been continuously recorded since 1993, were analyzed. Seasonal data sets with gaps $>6$ days were omitted.

Begin and end of pollen seasons-pollination (PSBPSE) - were defined phenologically as first and last days of a year, reaching 10 pollen $/ \mathrm{m}^{3}$ (PC10) by alder, hazel and birch, and 5 pollen $/ \mathrm{m}^{3}$ (PC5) by grass species, respectively. The time in-between was considered the pollen season or its duration. Because 6 leap years fell into the study period, running days were preferred over calendar days.

The Zentralanstalt für Meteorologie und Geodynamik (ZAMG Wien-Salzburg) provided meteorological data from 1993-2018 in form of hourly and daily temperatures $\left({ }^{\circ} \mathrm{C}\right)$, precipitation $\left(\right.$ PREC in $\mathrm{mm}=\mathrm{L} / \mathrm{m}^{2}$ ) and relative humidity ( $\mathrm{RH}$ in \%). They were collected at the monitoring station in the city of Linz (M1), which is situated at $1 \mathrm{~km}$ from the pollen monitoring station. From hourly values, the highest temperature (HTD), the mean temperature (MTD) and the lowest temperature (LTD) of a day were derived. The mean daily warmth (MDW) was defined as integral of ${ }_{1} \int^{24}$ hourly temperatures $>0{ }^{\circ} \mathrm{C} / 24 \mathrm{~h}$ and the cumulated one as daily MDW summed up from January 1 $\left(\mathrm{MDW}_{\text {cumul }}\right)$. In contrast, the mean daily frost (MDF) was regarded the integral of $\int_{1}{ }^{24}$ hourly temperatures $<0{ }^{\circ} \mathrm{C} / 24 \mathrm{~h}$. Thus frost and cumulated frost (MDF $\mathrm{Mumul}_{\text {, }}$ summed up beginning at January 1) reflect temperatures $<0^{\circ} \mathrm{C}$. Thereby, the freezing point of water was considered the physiological threshold for plant life.

For the meteorologically driven start of the pollen season, especially for early flowering plants, both, the cumulated mean daily warmth $\left(\mathrm{MDW}_{\text {cumul }}=\mathrm{MDW}\right.$ summed up from January 1) and a distinct threshold of HTD were considered necessary. The influence of frost was studied by using the $\mathrm{MDF}_{\text {cumul }}$. Between 1993 and $1999 \mathrm{MDW}_{\text {cumul }}$ and $\mathrm{MDF}_{\text {cumul }}$ were derived from semi-hourly temperatures of the meteorological station M2, about $2.2 \mathrm{~km}$ away from the pollen monitoring station. These data originate from the Upper Austrian Air Quality Monitoring Station, OÖ Luftmessnetz. From 2000 onward, only hourly temperature data of the ZAMG (M1) were used.

For figures, tables and regression analyses Microsoft Excel (Microsoft Excel 2003 and 2010, Microsoft Corporation, Redmont, WA, USA) and SigmaPlot, Systat Software (SigmaPlot 11, Systat Software, Incorporation, CA, USA) were used with their implemented analytical functions.

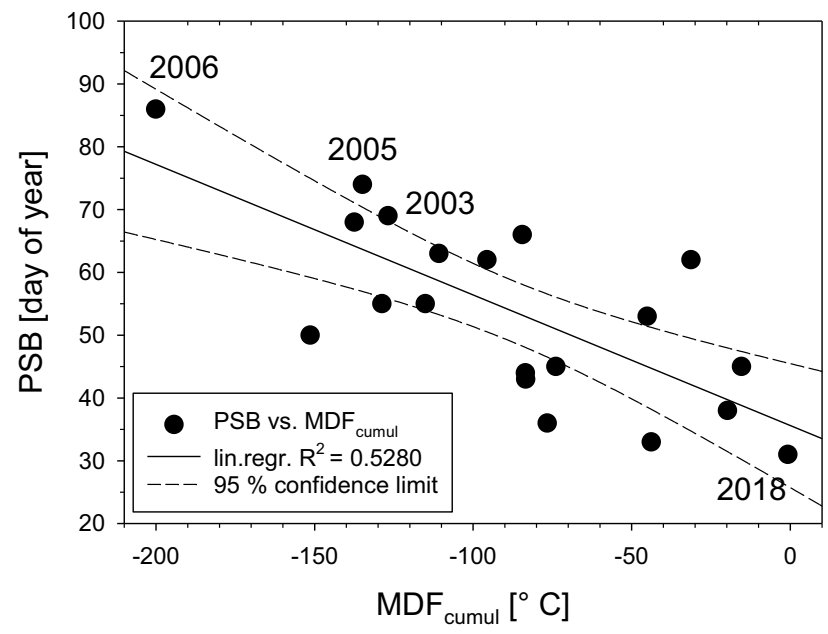

Fig. 2 Beginning of bloom of alder vs. frost [MDF ${ }_{\text {cumul] }}$. The linear regression $\left(R^{2}=0.528 ; p=0.002\right)$ shows that frost $\left(\mathrm{MDF}_{\text {cumul }}\right)$ delayed the start of flowering from 1993 to 2018 (19 seasons). Compared to 2018 the longest delays were found in the years 2005 and 2006. In 2006, a maximum of frost was observed. The $95 \%$ limits are depicted. $M D F_{\text {cumul }}$ mean daily frost cumulated from day January 1 for each year, $P S B$ beginning of pollination/pollen season 
Table 1 Begin of pollen seasons/pollination (PSB) of hazel, alder, birch and grass according to their PC thresholds (PC10 and PC5) between 1993 and 2018

\begin{tabular}{|c|c|c|c|c|}
\hline $\begin{array}{l}\text { Begin of pollina- } \\
\text { tion (PSB) }\end{array}$ & $\begin{array}{l}\text { Hazel } \\
\text { PC10 day }\end{array}$ & $\begin{array}{l}\text { Alder } \\
\text { PC10 day }\end{array}$ & $\begin{array}{l}\text { Birch } \\
\text { PC10 day }\end{array}$ & $\begin{array}{l}\text { Grass } \\
\text { PC5 day }\end{array}$ \\
\hline Shift forward & None & None & None & Tendency \\
\hline Significance & $p=0.34$ & $p=0.88$ & $p=0.59$ & $p=0.062$ \\
\hline Mean & 55.4 & 51.7 & 93.0 & 118.6 \\
\hline Standard error & 3.43 & 2.90 & 1.79 & 2.40 \\
\hline Median & 58.5 & 50.0 & 91.5 & 117.0 \\
\hline $\begin{array}{l}\text { Standard devia- } \\
\text { tion }\end{array}$ & 15.35 & 12.64 & 7.16 & 8.98 \\
\hline Minimum & 31 & 31 & 81 & 107 \\
\hline Maximum & 86 & 74 & 109 & 136 \\
\hline Seasons & 20 & 19 & 16 & 14 \\
\hline $\begin{array}{l}S D \% \text { Mean (coeffi- } \\
\text { cient } \\
\text { of variation) }\end{array}$ & 27.7 & 24.4 & 7.7 & 7.6 \\
\hline \multicolumn{5}{|c|}{$\begin{array}{l}\text { Begin of pollination/pollen season (PSB) and its statistical spread (= corrido } \\
\text { of PSB) } \\
\text { PC5 pollen concentration } 5 \text { pollen } / \mathrm{m}^{3}, P C 10 \text { pollen concentration } \\
10 \text { pollen } / \mathrm{m}^{3}\end{array}$} \\
\hline
\end{tabular}

\section{Results}

\section{Alder (Alnus) and hazel (Corylus)}

\section{Pollen season (PS) - start, course and duration of pollination}

Frost significantly delayed PSB (the begin of the pollen season) of alder. The greatest delays were observed 2006 (maximal frost at day 86), 2005 and 2003 (Fig. 2). The high variance of PSB (Table 1) is explained by varying phases and intensities of frost.

Fig. 3 revealed that frost has postponed flowering and pollination, respectively, of hazel if the necessary levels of $\mathrm{MDW}_{\text {cumul }}$ and HTD threshold were (are) not reached in time. Due to the warm January 2018, being almost free of frost, the pollen seasons of hazel and alder started as early as January 31 . On this day, $\mathrm{MDW}_{\text {cumul }}$ was found to be $126.4^{\circ} \mathrm{C}$ and the maximal HTD 1-5 days before PSB $11.2^{\circ} \mathrm{C}$ (Table 2). On average, $\mathrm{MDW}_{\text {cumul, }}$ reflecting the preseasonal thermal energy, must have reached a relatively constant $103.8^{\circ} \mathrm{C}$ (median $99.9^{\circ} \mathrm{C}$ ) and $\mathrm{HTD}_{\text {cumul }}$ mean $175.1^{\circ} \mathrm{C}$, before the bloom could start.

Years with an early PSB were associated with prolonged PS. As PS duration of hazel correlated significantly with raised daily temperatures $\left(\mathrm{R}^{2}=0.72\right.$; $p<0.001$ ), pollination was prolonged in warm years, but not combined with higher SPIn.

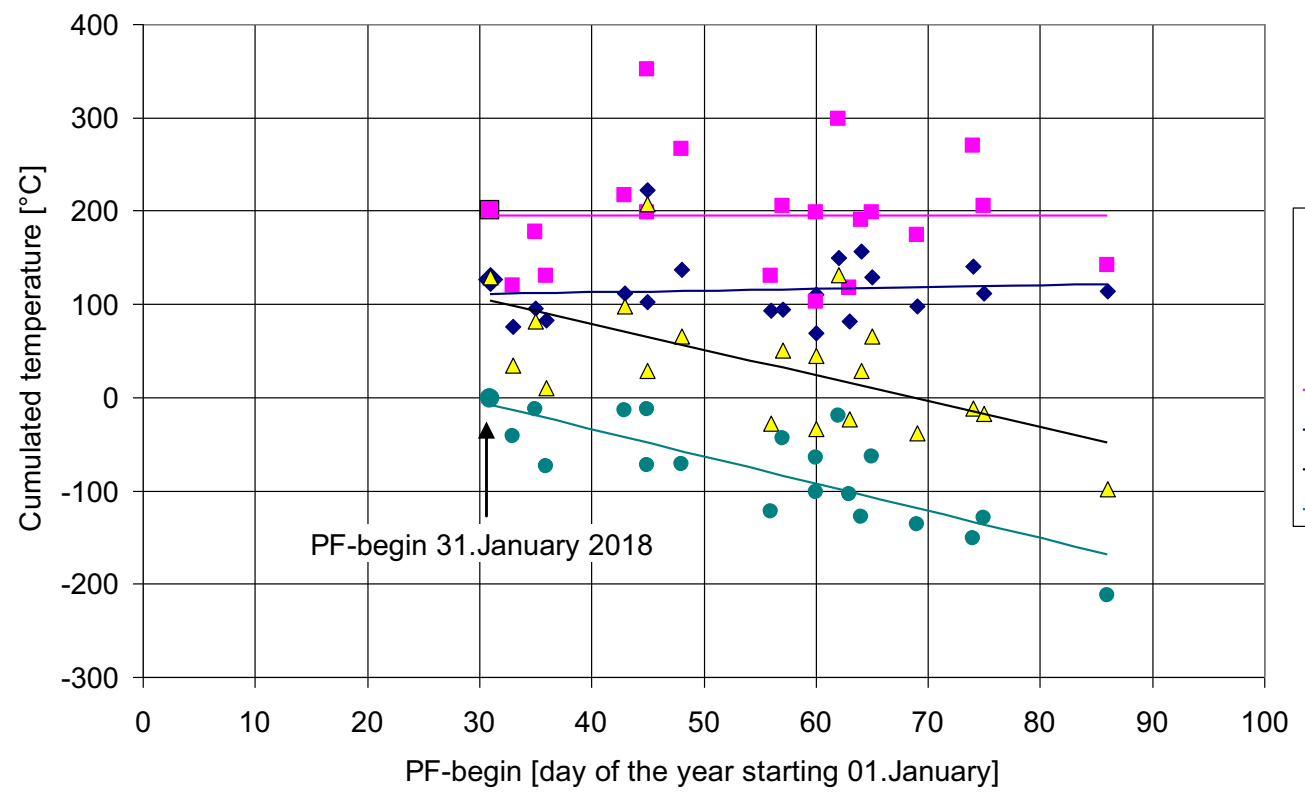

$$
\begin{gathered}
y=0.0096 x+193.96 \\
R^{2}=5 E-06 \quad p=n . s . \\
y=0.1861 x+104.93 \\
R^{2}=0.0066 \quad p=n . s .
\end{gathered}
$$

\begin{tabular}{ll}
- & HAZEL MDWcumul \\
& HAZEL HTDcumul \\
$\triangle$ & HAZEL MTDcumul \\
- & HAZEL MDFcumul \\
- & Linear (HAZEL HTDcumul) \\
- Linear (HAZEL MDWcumul) & Linear (HAZEL MTDcumul) \\
\hline & Linear (HAZEL MDFcumul)
\end{tabular}

$y=-2.7541 x+188.73$

$R^{2}=0.3501 p=0.006$

$y=-2.9208 x+82.777$

$R^{2}=0.6353 p<0,001$

Fig. 3 Hazel-cumulated temperatures at the onset of pollination between 1993 and 2018 (20 seasons) [MDW cumul, MTD $D_{\text {cumul, }} \mathrm{HTD}_{\text {cumul, }} \mathrm{MDF}_{\text {cumul]. The }}$ cumulated mean daily warmth/temperature $>0{ }^{\circ} \mathrm{C}$ ( $\mathrm{MDW}_{\text {cumul }}$ ) is considered to be the driving force for the development of catkins. At PSB it must have reached $104.6^{\circ} \mathrm{C}$. In a similar way, the HTD summed up from January 1 ( $\left.\mathrm{HTD}_{\text {cumul }}\right)$, should have risen to constant $194.9^{\circ} \mathrm{C}$. Frost (MDF cumul, mean daily frost cumulated) shifted pollination backwards, until MDW cumul $_{\text {and }} \mathrm{HTD}_{\text {cumul }}$ levels for flowering were reached. The mean daily tempera-

tures summed up (MTD $\left.\mathrm{D}_{\text {cumul }}\right)$ contain a similar information as $\mathrm{MDF}_{\text {cumul }}$ but are less closely correlated with PSB $\left(\mathrm{R}^{2}=0.35\right.$ vs 0.635). In 2018, PFB occurred at day 31 , the earliest in 26 years, being caused by minimal preseasonal frost in January of only $\mathrm{MDF}_{\text {cumul }}-0.9^{\circ} \mathrm{C}$. MDW cumul mean daily warmth cumulated from January 1 of each year, $H T D_{\text {cumul }}$ highest temperature of a day cumulated from January 1 of each year, $M T D_{\text {cumul }}$ mean temperature of a day cumulated from January 1 of each year, $M D F_{\text {cumul }}$ mean daily frost cumulated from January 1 of each year 
Table 2 Relationship between highest temperature of a day and beginning of the pollen seasons (PSB) of hazel (Corylus), alder (Alnus), birch (Betula) and grass (Poaceae)

\begin{tabular}{|c|c|c|c|c|}
\hline \multirow{2}{*}{$\begin{array}{l}\text { Highest temperature of a day } \\
\text { At the begin of the pollen season (PSB) }\end{array}$} & & \multicolumn{3}{|c|}{ HTDC @ PSB } \\
\hline & & Median & Mean \pm 1 SD & Range \\
\hline \multirow[t]{2}{*}{ HAZEL (Corylus) PC5 } & Day 0 & 11.10 & $9.95 \pm 5.02$ & $1.5-18.1$ \\
\hline & Day -1 to -5 & 11.05 & $10.79 \pm 3.22$ & $4.4-16.9$ \\
\hline \multirow[t]{2}{*}{ HAZEL (Corylus) PC10 } & Day 0 & 11.65 & $11.30 \pm 4.16$ & $2.7-18.1$ \\
\hline & Day -1 to -5 & 11.70 & $11.55 \pm 2.88$ & $5.1-16.9$ \\
\hline \multirow[t]{2}{*}{ ALDER (Alnus) PC5 } & Day 0 & 9.50 & $9.64 \pm 4.44$ & $1.5-16.2$ \\
\hline & Day -1 to -5 & 10.90 & $10.57 \pm 3.47$ & $4.1-16.9$ \\
\hline \multirow[t]{2}{*}{ ALDER (Alnus) PC10 } & Day 0 & 10.30 & $10.17 \pm 415$ & $1.5-16.6$ \\
\hline & Day -1 to -5 & 10.30 & $10.63 \pm 3.51$ & $4.5-16.9$ \\
\hline \multirow[t]{2}{*}{ BIRCH (Betula) PC10 } & Day 0 & 16.65 & $16.91 \pm 3.87$ & $10.5-23.9$ \\
\hline & Day -1 to -5 & 16.45 & $17.51 \pm 3.72$ & $9.7-23.1$ \\
\hline \multirow[t]{2}{*}{ BIRCH (Betula) PC100 } & Day 0 & 16.65 & $15.51 \pm 5.64$ & $4.6-23.9$ \\
\hline & Day -1 to -5 & 16.65 & $17.54 \pm 3.89$ & $10.6-23.1$ \\
\hline \multirow[t]{2}{*}{ GRASS (Poaceae) PC5 } & Day 0 & 20.05 & $20.00 \pm 4.06$ & $13.2-29.7$ \\
\hline & Day -1 to -5 & 21.35 & $21.10 \pm 3.16$ & $15.2-26.0$ \\
\hline \multirow[t]{2}{*}{ GRASS (Poaceae) PC10 } & Day 0 & 19.95 & $19.76 \pm 6.66$ & $8.7-30.2$ \\
\hline & Day -1 to -5 & 22.95 & $23.14 \pm 3.50$ & $14.9-29.4$ \\
\hline
\end{tabular}

temperature 1 to 5 days prior to PSB, SD standard deviation

Influence of frost on flowering and pollen production of alder and hazel

Weak episodes of frost with $\mathrm{MDF}_{\text {cumul }}$ just below $0{ }^{\circ} \mathrm{C}$ preceded the PSB of hazel and alder in 2018 (Fig. 4). In 2018 from February 24 to March 4, a cold spell interrupted the pollination of hazel. The bloom of alder started together with hazel, but showed a low $\mathrm{PC}$ at the beginning. The maximum expansion was delayed. It revealed two major peaks, which were abruptly stopped by a second cold spell between March 18 and March 22. With alder, neither frost before nor after PSB has caused damages. In 2018, the lowest LTDs of -4.6 down to $-9.1^{\circ} \mathrm{C}$ were observed between day 56 and 61 , occurring 5 to 8 days before the first main pollen peak. Looking only at the pollination in 2018 , it could be concluded that chills lead to pulsed PCs in a time- and dose-dependent manner. However, taking all years from 1993 to 2018 into account, it can be shown that the SPIn were correlated linearly positive with cumulated frost up to the end of pollination $\left(\mathrm{MDF}_{\text {cumul }} \mathrm{R}^{2}=0.196 ; p=0.0575\right)$, and negative with warmth $\left(\mathrm{MDW}_{\text {cumul }} \mathrm{R}^{2}=0.276, p=0.021\right)$. This revealed that temperatures below and slightly above zero degree positively affected SPIn. No close relationship, regarding the timing, was found. In contrast to alder, SPIn of hazel was not influenced by frost $\left(\mathrm{R}^{2}<0.1\right)$. On the contrary, warm temperatures increased the SPIn of hazel up to $\mathrm{MDW}_{\text {cumul }}$ of about $500^{\circ} \mathrm{C}$, levelling off there.

\section{Birch (Betula)}

\section{PS-start and duration}

Between 1993 and 2018, PSB has not varied much around day 91.5 (median) and days 93.0 \pm 7.2 (arithmetic mean \pm 1 SD; Table 1). At PSB on April 2 in 2018, the cumulated temperature for the final development of catkins $\left(\mathrm{MDW}_{\text {cumul }}\right)$ reached $314.2^{\circ} \mathrm{C}$ and HTD 13.7 to $14.5^{\circ} \mathrm{C}$, respectively. Fig. 5 shows for birch how the time-corridor of PSB is determined by three interacting variables: (1) the species specific PSB, (2) the cumulated warmth $\left(\mathrm{MDW}_{\text {cumul }}\right)$ as driving force, and (3) the HTD threshold as the final trigger for the opening of the male catkins. Over all seasons, frost delayed the PSB only marginally $\left(\mathrm{R}^{2}=0.22 ; p=0.066\right)$. The thermal energy demanded for PSB (bloom) remained relatively constant at $\mathrm{MDW}_{\text {cumul }} 336.1 \pm 55.8$ (mean $\pm 1 \mathrm{SD}$; median $335.4^{\circ} \mathrm{C}$ ). In 16 seasons, the threshold of HTD 1 to 5 days prior to PSB amounted to $17.5 \pm 3.7^{\circ} \mathrm{C}$ ( Table 2). Similar corridors for the PSB of alder and hazel can be constructed.

The length of PS of birch increased significantly with intraseasonal temperatures $>0{ }^{\circ} \mathrm{C} \quad\left(\mathrm{MDW}_{\text {cumul }}\right.$ $\mathrm{R}^{2}=0.7953 ; p<0.001$ ), but the influence of precipitation was negligible ( $\left.\mathrm{DP}_{\text {cumul }} \mathrm{R}^{2}=0.14 ; p=0.15\right)$. A unique situation occurred in 2018, when heat waves caused drought, which together shortened PS duration (Fig. 6a).

\section{Impact of low preseasonal temperatures on pollen productivity of birch}

In 2003, birch showed the highest SPIn. The years 2004, 2005 and 2006 ranged similar to 2018 above the 
Fig. 4 Influence of warm temperatures and frost on the pollen concentrations of alder (Alnus) and hazel (Corylus) in 2018. Minimal frost (MDF cumul $-0.9^{\circ} \mathrm{C}$ ) in January before bloom started on day 31 where $\mathrm{MDW}_{\text {cumul }}$ of $126.4^{\circ} \mathrm{C}$ (dashed line) coincided with the HTD threshold of $11.2^{\circ} \mathrm{C}$. Hazel revealed the same PSB criteria. Frost in February and March interrupted the bloom of hazel and delayed the main phase of alder. Even the lowest temperatures did not harm the flowering of alder. On the contrary, they stimulated the production of pollen. $P C$ pollen count/ concentration (per cubic meter), $M D F_{\text {cumul }}$ mean daily frost, $M D W_{\text {cumul }}$ mean daily warmth/temperature $>0{ }^{\circ} \mathrm{C}$, HTD highest temperature of a day. Pollen counts of alder from January 31 to April 30

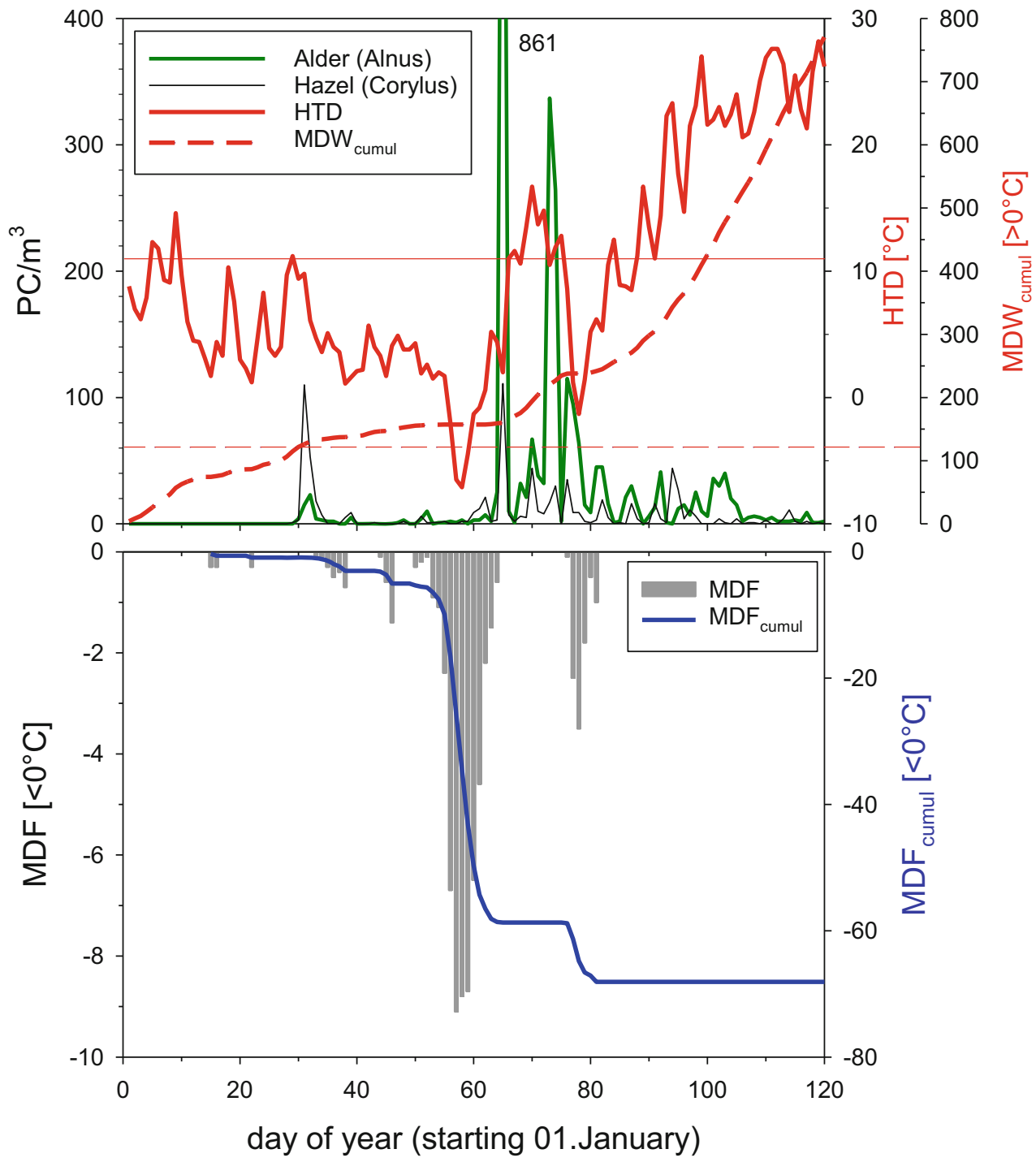

26-year trend [18]. In 2003, the lowest MDFs of -4.1 to $-5.2^{\circ} \mathrm{C}$ were recorded between day 45 and 49 , occurring 57 to 65 days before the first major pollen peak. No relationship between timing and SPIn was found. Similar to alder, the SPIn of birch correlated negatively with preseasonal warm temperatures $\left(\mathrm{MDW}_{\text {cumul }}\right.$ $\mathrm{R}^{2}=0.3259 ; p=0.0209$ ), indicating that cooler temperatures stimulate pollen production (SPIn) (Fig. 6b).

\section{Grasses (Poaceae)}

\section{PS - start and duration}

Over the years, a tendency towards an earlier start of PS was observed. In 2018, the earliest occurred on day 107. The PS duration has remained rather constant over the years $\left(\mathrm{R}^{2}<0.1\right)$. The pollen seasons with PC5 lasted 106.1 \pm 17.2 days (mean \pm 1 SD), and 108 days in 2018.

In 2018, the pollen season began earlier than in the years from 1994 to 2017; correspondingly the main pollen peak was shifted forward (Fig. 7a). As the num- ber of pollen peaks was similar in 2018 [26] to the years 1994-2017 [30], it is assumed that they were caused by pulsed or successive flowering of different grass species. The higher amplitude of pollen peaks in the first half of PS might be caused by species with a higher pollen production [27]. Haying may lower PCs in the second half of the PS.

\section{Influence of changing wet and dry conditions on the} pollen production of grass

There was a close correlation between cumulated preseasonal relative humidity $\left(\mathrm{RH}_{\text {cumul }}\right)$ and PSB $\left(\mathrm{R}^{2}=0.8826 ; p<0.001\right.$; Fig. 8a). It exceeded that of temperature $\left(\mathrm{MDW}_{\text {cumul }} \mathrm{R}^{2}=0.3173 ; p=0.005\right)$ and precipitation $\left(\mathrm{PREC}_{\text {cumul }} \mathrm{R}^{2}=0.3377 ; p=0.004\right)$, which are both needed for growth of plants and development of their blossoms. RH represents precipitation, soil moisture and evaporation in relation to temperature. RH decreases substantially during hot days. Low $\mathrm{RH}$ indicates dryness (=deficit in water supply, diminished evaporation). Dryness, respectively drought, 


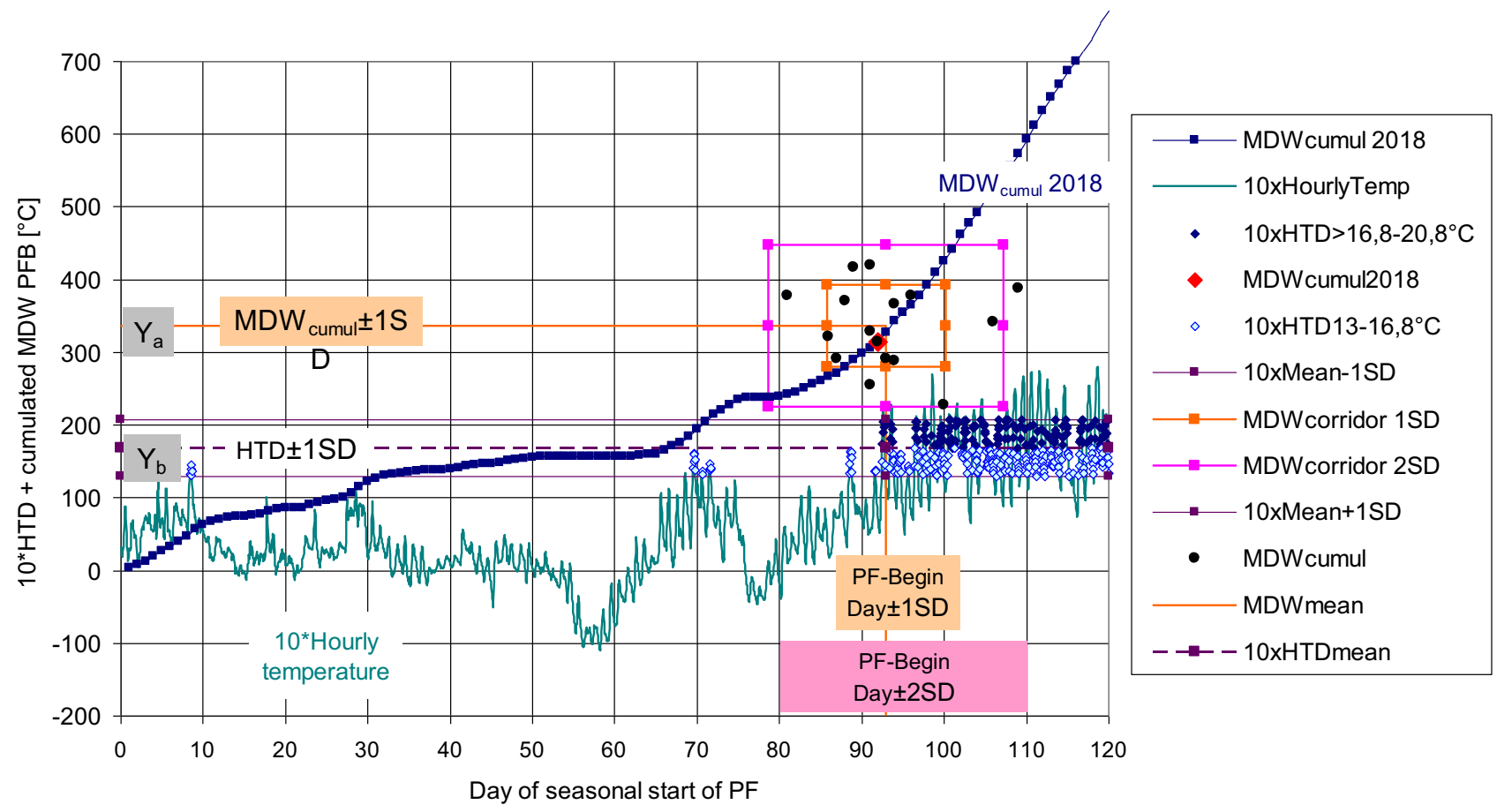

Fig. 5 Corridor of the beginning of the birch bloom (PSB of Betula). The PS start between 1993 up to 2017 has been around day $93.0 \pm 14.2$ (mean $\pm 2 S D$; median 91.5, range 81-109; $\mathrm{x}$-axis). PSB starts at the coincidence of cumulated warm temperatures reaching a certain level (MDW cumul $\mathrm{M} \pm 1 \mathrm{SD} 336.1 \pm 55.8^{\circ} \mathrm{C} ; \mathrm{y}$-axis, $\mathrm{Y}_{\mathrm{a}}$ ) and of the highest temperature of a day surmounting a certain threshold $\left(H T D_{\text {minim }}>13.6^{\circ} \mathrm{C}\right.$ over the last 5 days before PFB or $>13^{\circ} \mathrm{C}$ on the day of PSB; $y$-axis, $Y_{b}$ ) within the expected species specific period of the PSB. Superimposed are MDW $_{\text {cumul }}$

leads to an earlier onset of PS, whilst wet and warm weather conditions delay the bloom of grass. Because of the highly significant correlation between $\mathrm{RH}_{\text {cumul }}$ and PSB, RH offers a powerful tool in forecasting the PSB of grass. The highest SPIn were recorded in the years 1994, 2001, 2002 and 2004. Over 25 years, the yearly means of RH have decreased continuously from 79 to $71 \%\left(\mathrm{R}^{2}=0.699 ; p<0.001\right)$. Finally in 2018 , $\mathrm{RH}$ reached a minimum of about $67 \%$, indicating a continuous development towards drier and warmer semi-arid conditions. SPIn $\left(\mathrm{R}^{2}=0.36 ; p=0.024\right)$ and the PCs of the main pollen peaks $\left(\mathrm{R}^{2}=0.32 ; p=0.035\right)$ decreased synchronously from 1994 to 2018. Because of data gaps (11 out of 25 years were missing), some uncertainty remained regarding the interpretation of the linear decline over 25 years. The polynomial regression of SPIn revealed a biphasic curve with an $\mathrm{R}^{2}=0.39$. SPIn could have stabilized at a lower level between 2005 and 2018 (Fig. 7b).

\section{Discussion}

In Linz, temperatures have risen during the summer more than during the winter half-year over a period of 26 years. While temperatures below zero have hardly and hourly temperatures $\left({ }^{*} 10\right)$ of 2018 starting on January 1. In 2018 PS of birch began on day 92 at a MDW cumul of $314.2^{\circ} \mathrm{C}$ (representing the final development forcing temperature ) coinciding with $\mathrm{HTD}_{\text {minim }}$ (minimal temperature for opening of the catkins ) of 13.7 to $14.5^{\circ} \mathrm{C}$. MDW cumul and HTD threshold in combination could be used for the meteorological forecast of the PSB. MDW cumul cumulated mean daily warmth/temperatures $>0^{\circ} \mathrm{C}, H T D$ highest temperature of a day, $P S$ pollen season/pollination, $P S B$ beginning of pollen season/pollination

decreased over the years, $\mathrm{MDW}_{\mathrm{ym}}$ has increased by $0.056^{\circ} \mathrm{C}$ a year $\left(\mathrm{R}^{2}=0.4151 ; p<0.001\right)$. The correlation between warming and decline of frost was highly significant $\left(\mathrm{R}^{2}=0.519 ; p=0.00002\right)$, indicating both a reduction in intensity as well shortening of the frost periods in winter [28]. In contrast to temperature, precipitation has shown only a minor decrease. Overall, the climate became warmer and drier, which is reflected in a significant and progressive decline of relative humidity $(\mathrm{RH})$. Because Linz is located in a region with low precipitation, borderline situations such as drought and urban overheating might occur earlier. When the observed weather trends continue, the exceptional year 2018 might anticipate what in about 20 years will be considered "normal".

The year 2018 was an exceptionally warm and dry year in Linz, with temperatures significantly above and precipitation below average in 10 of 12 months. Cold spells during February and March characterised the year as a hybrid one. Cool weather conditions during this time stimulated the production of pollen of alder and birch.

Climate warming over the past 26 years did not show a statistically significant increase in seasonal pollen production (SPIn). Instead, fluctuations in pre- 
Fig. 6 a Duration of the pollen season of birch (Betula) 1993 to 2018. In the period from 1993 to 2018 (16 seasons), the duration of PS has increased significantly with rise of intraseasonal temperatures (MDW cumul $\quad R^{2}=0.7953$; $p=0.00018$ ). Precipitation on the other hand

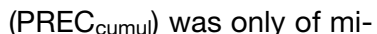
nor importance $\left(R^{2}=0.14\right.$; $p=0.15$ ). The situation of the dry and warm year 2018 is outstanding: High temperatures but hardly any precipitation reduced the PS duration to average. b Seasonal pollen concentrations of birch (Betula) from 1993 to 2018 (16 seasons). The seasonal pollen integrals (SPIn) reveal a negative linear correlation with the preseasonal cumulated mean daily temperatures $>0{ }^{\circ} \mathrm{C}$ (MDW cumul $_{\text {cul }}$ $\mathrm{R}^{2}=3.25 ; p=0.0209$ ). Warm weather lead to low pollen concentrations, while cooler temperatures increased them

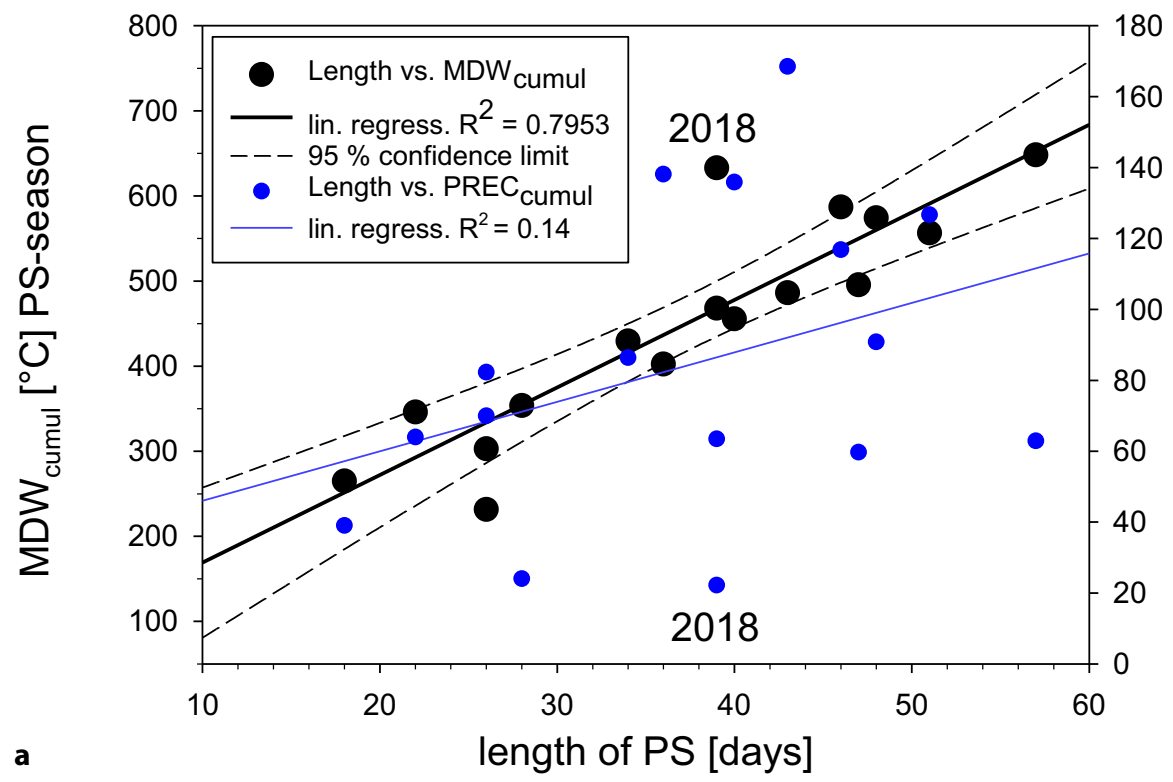

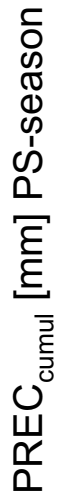

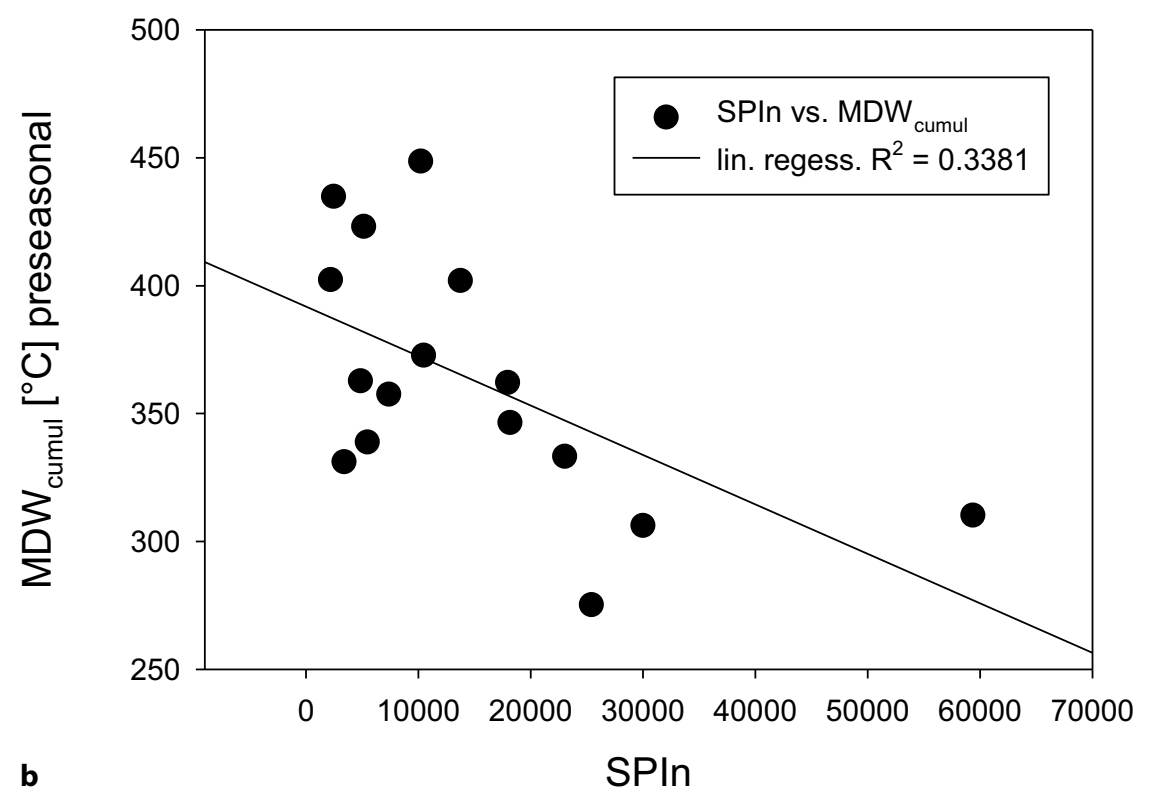

seasonal weather conditions were identified as primary drivers of the annual variance of PF of hazel, alder, birch and grass. Over the past 26 years, temperatures $>0{ }^{\circ} \mathrm{C}$ cumulated over the first 90 days of the year $\left(\mathrm{MDW}_{\text {cumul }}\right)$ did not reveal a significant change $\left(\mathrm{R}^{2}=0.023\right.$; n. s. $)$, which was quite in contrast to the rise of temperature over the whole year $\left(R^{2}=0.339\right.$; $p=0.0018$ ). The phenological reasons and biological laws underlying the observed high variance are discussed. In the future, a forward shift of the pollen seasons of birch and grass is expected first. It appears that this has already begun with grass.

The vegetative and generative development of catkins of the early flowering trees and shrubs already starts in the previous summer. During the following spring the species-specific coincidence of cumu- lated forcing temperatures ( $\mathrm{MDW}_{\text {cumul }}$ ) and a distinct minimal temperature threshold (HTD) as the final signal for catkin opening is necessary for the start of bloom. These interrelationship is illustrated in the "pollination-onset-corridor model" exemplified for birch-analogously, corridor-models can be constructed for hazel and alder. They provide the base for the annual forecast of the PSB. Frost was the third meteorological parameter determining PSB. Frost delayed the start of PS of hazel and alder and explained its high variance. Frost was maximal in 2006. There the pollen season started 55 days later than in 2018. Warm winters with little frost shifted forward the PSB of hazel and alder. Despite the variability over the past 26 years, the preseasonal MDW $_{\text {cumul }}$ as well as the HTD threshold have remained relatively constant, 

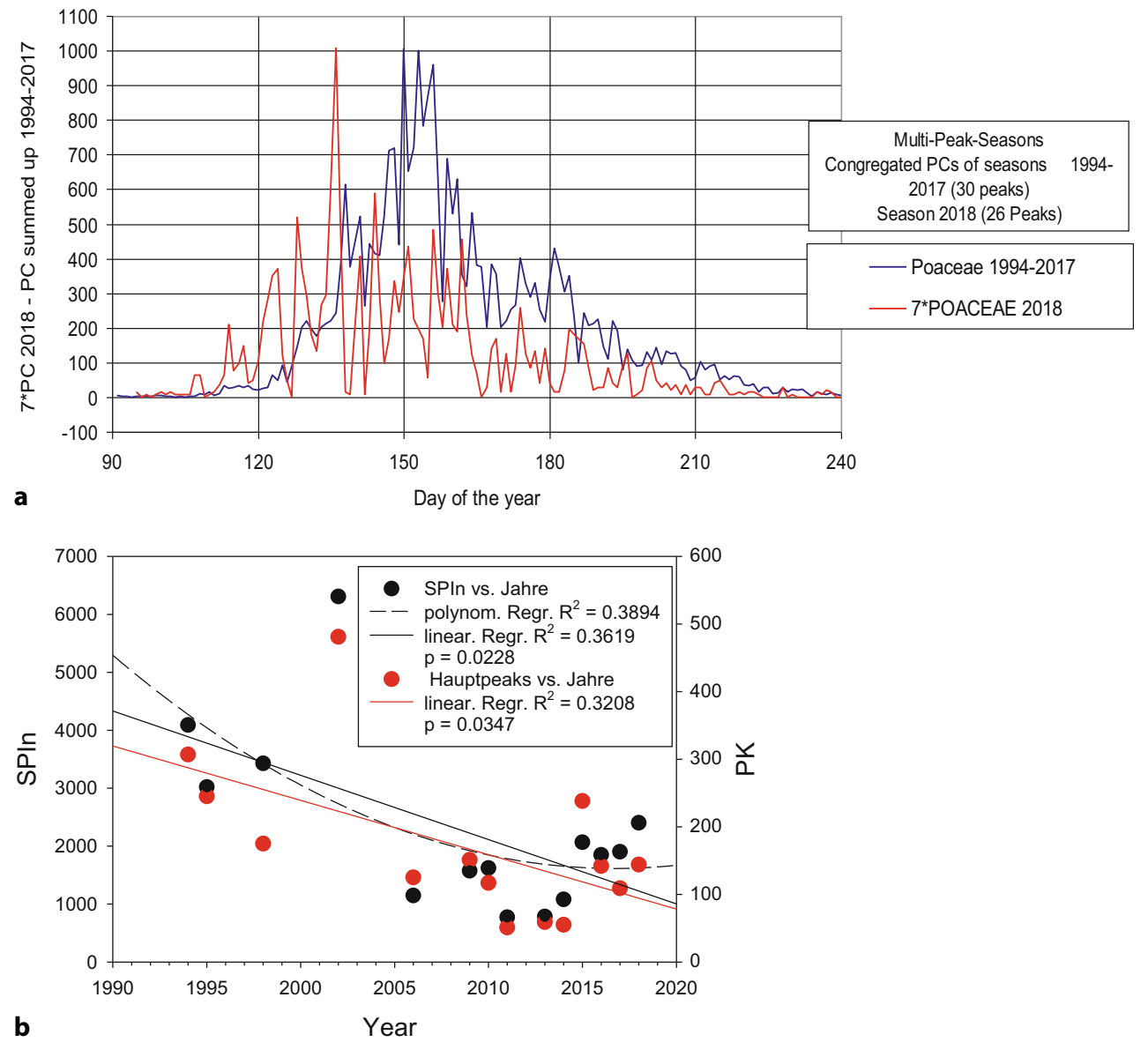

Fig. 7 a Grass species (Poaceae)-pollen season of 2018 compared to the mean of 13 congregated seasons between 1994 and 2017. In 2018, the PCs are higher especially in the 1 st half than in the 2 nd half. The multipeak profile is detectable in both 2018 and earlier seasons; similar to the number of pollen peaks, it is assumed that they were caused by pulsed or successive flowering of different grass species. In 2018, the pollen season began earlier than in the years from 1994 to 2017 ; correspondingly the main pollen peak was shifted

forward. b Grass species (Poaceae), 1994-2018 seasonal pollen integrals and main peaks (14 seasons). Applying linear regression analysis, both decrease, SPIn with $R^{2}=0.3619$ and $p=0.02228$, and main pollen peaks with $R^{2}=0.3208$ and $p=0.0347$. With polynomial regression, SPIn has stabilized at a lower level between 2005 and 2018. PS pollen season/pollen count, $P C$ mean pollen concentration of a day noted as pollen/ cubic meter $\left(\mathrm{m}^{3}\right)$ air, SPIn seasonal pollen integrals

indicating that they are the main drivers for the start of PS.

It is important to outline that different mechanisms drive PSB and pollen production (SPIn) of hazel, alder and birch. In 2018, frost interrupted the flowering of hazel and alder. On the other hand, preseasonal frost and cool temperatures stimulated SPIn of alder, while hazel required warmer conditions. The birch showed the paradox that it needed higher temperatures for flowering compared to hazel and alder, but cooler temperatures to stimulate SPIn [18]. The underlying mechanisms are unknown. With respect to the nordic/alpine and mountainous distribution of Silver birch (Betula pendula) and Gray alder (Alnus incana), this appears to be a reasonable strategy, since spring frost mainly determines the borders of vegetation in these areas [29]. The stimulation of hazel by warmer temperatures could be related to its origin from Southeastern Europe and Asia Minor. The

warmth-frost hypothesis could explain variations in SPIn of hazel, alder and birch with stimulation of flowering in colder years and an earlier PSB in warmer years lacking frost. The year 2003 revealed the highest SPIn of alder and birch. Such years rich in pollen ("mast years") could be explained by the synergy of preseasonal stimulation of pollen production by cold/ frost together with enhanced budding during the previous year [30]. Higher temperatures during the pollen season prolonged the PS of birch, hazel and alder. However, heat waves combined with drought, like in 2018, shortened the pollen season of birch. This circumstance is pertinent for the intensity of the birch pollen load in overheated urban areas. In contrast to the impact of preseasonal temperatures on SPIn of early bloomers, warm temperatures during the pollen seasons only played a minor, modifying role.

With grass, the earliest start of PF was seen in 2018. It was caused by dryness and rather warm tempera- 
Fig. 8 a Grass species (Poaceae)-relative humidity and onset of pollination. Applying multivariate analysis, $\mathrm{RH}_{\text {cumul }}$ dominates the forecast of PSB $\left(\mathrm{R}^{2}=0.8787 ; p=4.37 \times 10^{-11}\right)$ so much that both underlying factors $\mathrm{MDW}_{\text {cumul }}$ $\left(\mathrm{R}^{2}=0.317 ; \quad p=0.0051\right)$ and PREC cumul $\left(R^{2}=0.338\right.$; $p=0.0036$ ) become unimportant. Because of the significant relation between $\mathrm{RH}$ and $\mathrm{PSB}, \mathrm{RH}_{\text {cumul }}$ could be preferentially used predicting the PSB of grass. b Yearly means of relative humidity from 1993 to 2018. There is a continuous drop of relative humidity over 26 years, which points to the development towards a semiarid climate. $R H$ relative humidity, $P S B$ beginning of pollination/pollen season, $M D W_{\text {cumul }}$ cumulated mean warmth/temperatures $>0^{\circ} \mathrm{C}, P R E C_{\text {cumul }}$ daily precipitation cumulated from January 1 on dryness (RHdeficit) shifts PSB of grass forward
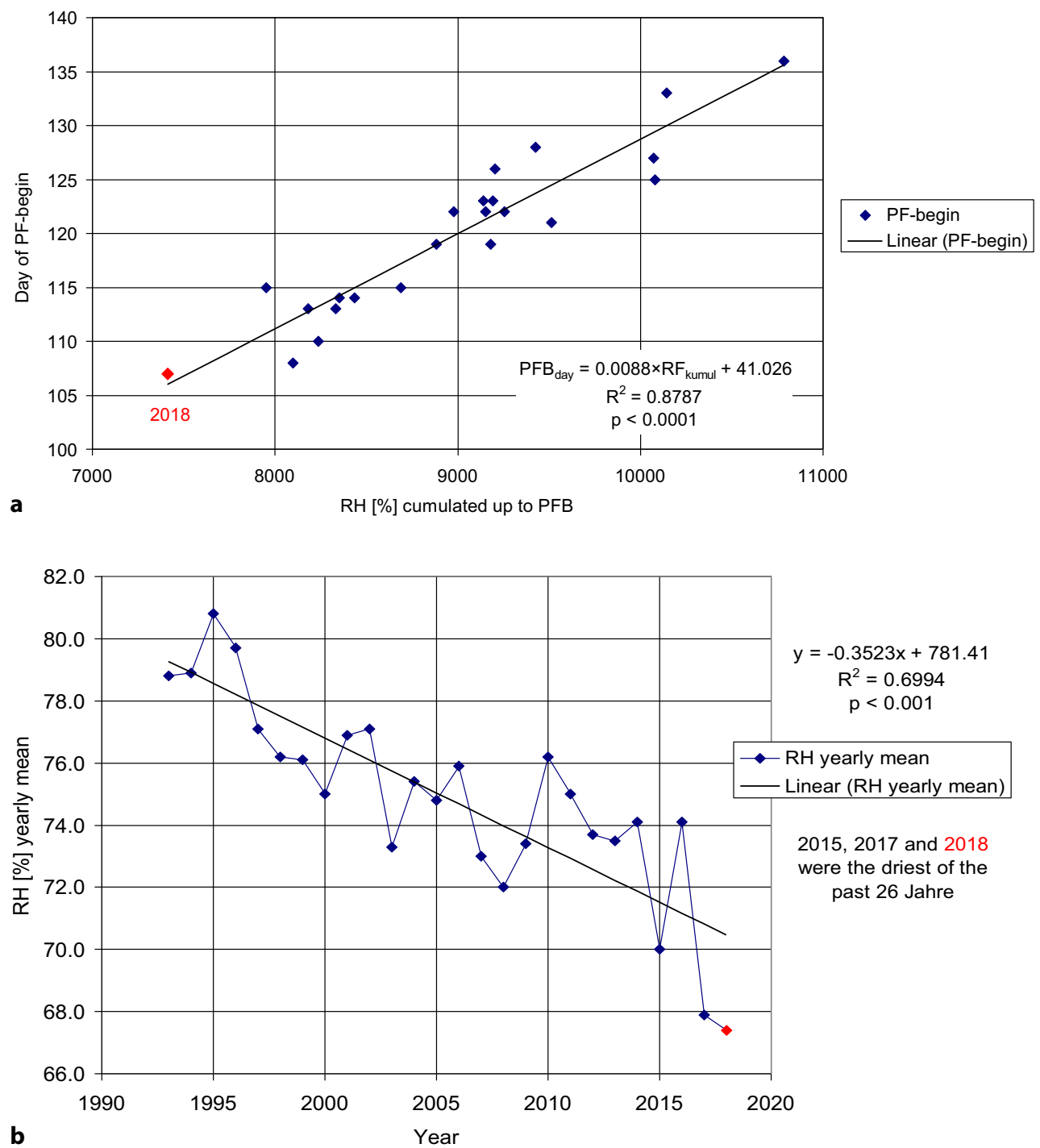

tures in April. The lowest relative humidity (RH) ever found reflected the ratio of dryness to temperature. Over 26 years not only the cumulated RH has fallen progressively (Fig. 8a), but by itself $\mathrm{RH}_{\text {cumul }}$ has turned out to be the best predictor for PSB of grass (Fig. 8b). Applying multivariate analysis, $\mathrm{RH}_{\text {cumul }}$ dominated the prediction of PSB so much that MDW and DP $\mathrm{Puml}_{\text {cum }}$ became minuscule/unimportant. Wet weather combined with warm temperatures shifted the PSB backwards in contrast to a forward shift by dry and warm conditions. From 1994 to 2018 the SPIn of grass has dropped in a similar linear manner as the main peaks have.

Using a polynomial regression, a biphasic course was found, with SPIn stabilizing at a lower level from 2006 to 2018. In general, longer rainy periods lower PC. In 2018 they were replaced by episodic spells of rain. The latter pattern is predicted to occur more frequently with climate warming [31]. Rainy episodes could stimulate growth and pollen production over the following days [32, 33] and compensate at least in part for the reduced pollen release caused by dryness or even drought. Such compensating mechanisms could explain the mentioned stabilized SPIn of grass in recent years of climate warming. Over time the duration of PS of grass has remained relatively constant. Accordingly, the early start of grass bloom in 2018 was associated with an earlier end of the flowering season. This supports the hypothesis that an early spring might lead to an earlier end of vegetation in autumn [11].

Despite progressive climate warming over the last quarter of the century and elevated $\mathrm{CO}_{2}$ concentrations, the pollen concentrations of hazel, alder, birch and grass by trend analysis have not risen, on the contrary they have declined over time. The increase of pollen allergy and of the prevalence of sensitization especially in young people [34] cannot be explained directly by climate warming, but must have other reasons. Among them several other causative factors or complex interactions might be responsible: aerogenic ones like air pollution, alteration of allergens, toxic 
or combined toxic-allergic effects on humans as well as on plants; $\mathrm{NO}_{\mathrm{x}}, \mathrm{O}_{3}$, VOC (nitrogen oxides, ozone, volatile organic compounds, respectively) which by themselves can be related to climate change [35-37], or in general an urban environment. Apart from the mentioned factors there is a number of other nonaerogenic enhancers of sensitization and allergic reactions likely.

Acknowledgements We thank ZAMG (Zentralanstalt für Meteorologie und Geodynamik) Salzburg-Vienna (J. Haslhofer) and the Department of environmental protection of the office of Upper Austrian state government (R. Pürmayr) for their meteorological data; the environmental management of the city of Linz (W. Hager) for meteorological data; the EAN databank of the Austrian pollen warning system at the ENT University Clinic in Vienna (U. Berger, K. Bastl and M. Bastl); the technical team of the pollen information service at the Kepler University Clinics in Linz (J. Brungraber, P. Lichtenberger, A. Machik); the pollen analytics in Mondsee (J. Schmidt) as well as for their suggestions Ch. Körner (Basel), A. Pauling (Zurich), and H. Formayer (Vienna).

Funding Open access funding provided by Johannes Kepler University Linz.

Conflict of interest R. Schmidt has been working as a pollen analyst for the Austrian Pollenwarndienst over the past 32 years, but there is no conflict of interests with the present publication. H.A.E. Schinko and B. Lamprecht have no conflict of interests.

Open Access This article is licensed under a Creative Commons Attribution 4.0 International License, which permits use, sharing, adaptation, distribution and reproduction in any medium or format, as long as you give appropriate credit to the original author(s) and the source, provide a link to the Creative Commons licence, and indicate if changes were made. The images or other third party material in this article are included in the article's Creative Commons licence, unless indicated otherwise in a credit line to the material. If material is not included in the article's Creative Commons licence and your intended use is not permitted by statutory regulation or exceeds the permitted use, you will need to obtain permission directly from the copyright holder. To view a copy of this licence, visit http://creativecommons.org/licenses/by/4.0/.

\section{References}

1. ZwickH, Popp W, Jäger S, Wagner C, Reiser K, HorakF. Pollen sensitization and allergy in children depend on the pollen load. Allergy. 1991;46:362-6.

2. Popp W, Zwick H, Steyrer K, Rauscher H, Wanke T. Sensitization to aeroallergens depends on environmental factors. Allergy. 1989;44:572-5.

3. Stemeseder T, Klinglmayr E, Moser S, Lüftenegger L, Lang R, Himly M, et al. Cross-sectional study on allergic sensitization of Austrian adolescents using molecule-based IgE profiling. Allergy. 2017;72:754-63.

4. Haas W, Moshammer H, Muttarak R, Koland O, editors. Austrian Panel on Climate Change (APCC). Austrian special report health, demography and climate change (ASR18). Wien: Austrian Academy of Sciences Press; 2018. p. 331. https://austriaca.at/APCC_ASR18.pdf.

5. Ziello C, Sparks TH, Estrella N, Belmonte J, Bergmann KC, Bucher E, et al. Changes to airborne pollen counts across Europe. PLoS One. 2012;7:e34076.
6. Bergmann KC. Weatherconditions and climatechangehave an effect on allergies. Allergo J Int. 2016;25:131-7.

7. Zentralanstalt für Meteorologie und Geodynamik (ZAMG). 2018 mit großer Wahrcheinlichkeit wärmstes Jahr der Messgeschichte. 20.12.2018, p. 1-10. https://www.zamg.ac.at/ cms/de/klima/news/2018-mit-grosser-wahrscheinlichkeitwaermstes-jahr-der-messgeschichte. Accessed 04.12.2020.

8. Kromp-Kolb H, Formayer H, Haas P, Hofstätter M, Schwarzl I. Beobachtete Veränderung der Hitzeperioden in Oberösterreich und Abschätzung der möglichen zukünftigen Entwicklungen (Endbericht Band 1 der Forschungsreihe „Auswirkungen des Klimawandels auf Oberösterreich“, Februar 2007). BOKU-Met Report 12. 2009. pp. 1-31. https://meteo.boku.ac.at/report/BOKUMet_Report_12_online.pdf.

9. Menzel A, Sparks TH, Estrella N, Koch E, Aasa A, Ahas R, et al. European phenological response to climate change matches the warming pattern. Glob Change Biol. 2006;12:1969-76.

10. Peñuelas J, Rutishauser T, Filella I. Ecology. Phenology feedbacks on climate change. Science. 2009;324:887-8.

11. Keenan TF, Richardson AD. The timing of autumn senescence is affected by the timing of spring phenology: implications for predictive models. Glob Change Biol. 2015;21:2634-41.

12. Forkel M, Carvalhais N, Rödenbeck C, Keeling R, Heimann M, Thonicke $\mathrm{K}$, et al. Enhanced seasonal $\mathrm{CO}_{2}$ exchange caused by amplified plant productivity in northern ecosystems. Science. 2016;351:696-9.

13. Buermann W, Forkel M, O'Sullivan M, Sitch S, Friedlingstein P, Haverd V, et al. Widespread seasonal compensation effects of spring warming on northern plant productivity. Nature. 2018;562:110-4.

14. Bastl K, Kmenta M, Berger UE. Defining pollen seasons: background and recommendations. Curr Allergy Asthma Rep. 2018;18:73.

15. Fritz A. Der Pollen- und Sporenflug in Kärnten 1983 und 1984. Carinthia II. 1985;175/95:111-24. https://www. zobodat.at/pdf/CAR_175_95_0111-0124.pdf.

16. JägerS.TageszeitlicheVerteilungundlangjährigeTrendsbei allergiekompetenten Pollen. Allergologie. 1990;13:159-82.

17. Zwander H, Fischer-Wellenborn E, Romauch E. Der Pollenflug in Kärnten im Jahr 2001. Carinthia II. 2002;192/112:141-53. https://www.zobodat.at/pdf/CAR_ 192_112_0141-0153.pdf.

18. Schmidt R, Schmidt J, Schinko HAE. Aerobiologie - Erfahrungen aus 25 Jahren Pollenflug Linz. In: Schinko HAE, Schmidt R, Lamprecht B, editors. Pollen, der Mensch und die Stadt. Aeroallergie \& Aerobiologie, Interdisziplinäres Symposium 2011. Linz: Eigenverlag; 2011.pp.7-28.

19. LaubeJ, Sparks TH, EstrellaN, HöflerJ, AnkerstDP, MenzelA. Chilling outweighs photoperiod in preventing precocious spring development. Glob Change Biol. 2014;20:170-82.

20. PaulingA, Gehring R, ClotB. Toward optimized temperature sumparameterizations for forecasting the start of the pollen season. Aerobiologia. 2014;30:45-57.

21. Körner C, Basler D. Plant science. Phenology under global warming. Science. 2010;327:1461-2.

22. Barnes C, Pacheco F, Landuyt J, Hu F, Portnoy J. The effect of the temperature, relative humidity and rainfall in airborne ragweed pollen concentrations. Aerobiologia. 2001;17:61-8.

23. Jäger S, Hirnschall I, Hürbe E, Schmidt R, Wiesenberger W. Pollenwarndienst des Landes Oberösterreich (LKH Gmundnerberg) und der Stadt Linz (AKh Linz). Mitt Ärztekamm Oberösterreich. 1985;81:426-9. 
24. Galán C, Smith M, Thibaudon M, Frenguelli G, Oteros J, Gehrig R, et al. Pollen monitoring: minimum requirements and reproducibility of analysis. Aerobiologia. 2014;30:385-95.

25. Galán C, Ariatti A, Bonini M, Clot B, Crouzy B, et al. Recommended terminology for aerobiological studies. Aerobiologia. 2017;33:293-5.

26. Kmenta M, Bastl K, Kramer MF, Hewings SJ, Mwange J, Zetter R, etal. The grass pollen season 2014 in Vienna: a pilot study combining phenology, aerobiology and symptom data. Sci Total Environ. 2016;566-567:1614-20.

27. Schaumberger A. Räumliche Modelle zur Vegetations- und Ertragsdynamik im Wirtschaftsgrünland. Diss. Technische Universität Graz. 2011.

28. Medhaug I, Stolpe MB, Fischer EM, Knutti R. Reconciling controversies about the 'global warming hiatus'. Nature. 2017;545:41-7.

29. Lenz A, Hoch G, Vitasse Y, Körner C. European deciduous trees exhibit similar safety margins against damage by spring freeze events along elevation gradients. New Phytol. 2013;200:1166-531.

30. Masaka K, Maguchi S. Modelling the masting behaviour of Betula platyphylla var. japonica using the resource budget model. Ann Bot. 2001;88:1049-55.

31. Haslinger K, Schöner W, Anders I. Future drought probabilities in the Greater Alpine Region based on COSMO-CLM experiments—spatial patterns and driving forces. MeteorolZ. 2015;25:137-48.
32. Spieksma FTM, den Tonkelaar JF. Four-hourly fluctuations in gras-pollen concentrations in relation to wet versus dry weather, and to short versus long over-land advections. Int J Biometeorol. 1986;30:351-8.

33. Munoz Rodríguez AF, Palacios I, Molina R. Influence of meterological parameters in hourly patterns of grass (Poaceae) pollen concentrations. Ann Agric Environ Med. 2010;17:87-100.

34. Haftenberger M, Laußmann D, Ellert U, Kalcklösch M, Langen U, Schlaud M, et al. Prävalenz von Sensibilisierungen gegen Inhalations- und Nahrungsmittelallergene Ergebnisse der Studie zur Gesundheit Erwachsener in Deutschland (DEGS1). Bundesgesundheitsblatt Gesundheitsforschung Gesundheitsschutz. 2013;56:687-97.

35. Schinko HAE, MedingerW, HagerW. Pollen, Pollenallergene und partikuläre Luftschadstoffe - Aspektewandel. Allergologie. 1994;17:514-25.

36. SénéchalH, VisezN, CharpinD, ShahaliY, PeltreG, BiolleyJP, et al. A review of the effects of major atmospheric pollutants on pollen grains, pollen content, and allergenicity. ScientificWorldJournal. 2015; https://doi.org/10.1155/2015/ 940243.

37. Wooding DJ, Ryu MH, Hüls A, Lee AD, Lin DTS, Rider CF, et al. Particle depletion does not remediate acute effects of traffic-related air pollution and allergen. A randomized, double-blind crossover study. Am J Respir Crit Care Med. 2019;200:565-74. 